\title{
Negotiation and Dispute Prevention in Global Cooperative Institutions: International Community Interests, IUU Fishing, and the Biodiversity Beyond National Jurisdiction Negotiation
}

\author{
Cymie R. Payne \\ Associate Professor, School of Environmental and Biological Sciences and \\ School of Law, Rutgers University, NJ, US \\ cymie.payne@rutgers.edu
}

\begin{abstract}
In areas beyond national jurisdiction communitarian interests are vulnerable to a weak legal order, evidenced by the prevalence of IUU fishing. The negotiation of an agreement for conservation and sustainable use of marine biodiversity in areas beyond national jurisdiction (BBNJ) and the still-evolving jurisprudence for erga omnes obligations present opportunities to strengthen them through global cooperative institutions by empowering states and non-state actors. BBNJ bodies designed to lead effective cooperation with other regimes should be considered strengthening, not undermining, to the legal order of the ocean, as economic interests emphasized in other instruments may be enhanced in the long-term by the ввNJ agreement's planning, transparency, capacity building and technology transfer provisions. International courts have found that individual states have standing to represent community interests; non-state actors could also be recognized to have standing to access judicial fora when existential interests of humanity are at stake.
\end{abstract}

\section{Keywords}

international courts - International Court of Justice - high seas - erga omnes biodiversity - IUU fishing - B BNJ Agreement 
Disputes in areas beyond national jurisdiction (ABNJ) may be triggered by conflicting interests vying where there are weak or non-existent rules, differing interpretation of applicable rules, or attempts at enforcing compliance with obligations. The law can contribute to preventing and resolving such conflicts. However, in ABNJ, communitarian interests are vulnerable to a weak legal order. They can be strengthened by an effective treaty, reflecting international law obligations to prevent harm to the marine environment.

We can reasonably expect dispute settlement and advisory opinions provided by international courts and tribunals (ICTs) like the International Tribunal for the Law of the Sea (ITLOS), the International Court of Justice (ICJ) and arbitral tribunals to influence behaviour and consequently to prevent some illegal, unreported and unregulated (IUU) fishing. ICTs do this by providing guidance on the legal rules, enhancing legal clarity. This facilitates cooperation between states, because the agreed rules are known and understood. Legal clarity supports compliance and enforcement for the same reason. When an actor wishes to be compliant, she knows what she needs to do. When an actor is indifferent or wishes to be non-compliant, the enforcer is empowered to act - through litigation or other measures - because the activity is known to be an infraction.

Expecting ICT s to have the same influence over activities in marine ABNJ challenges the usual bilateral state-based system. True, the UN Convention on the Law of the Sea (UNCLOS), the Fish Stocks Agreement, and Regional Fishery Management Organizations (RFMOs) provide legal rules for ABNJ. ${ }^{1}$ Yet they have not prevented IUU fishing or solved the problem of how to represent the international community's interest in a healthy ocean.

Setting aside preconceptions of what is politically possible, this paper points to where law needs to develop: the lex ferenda. The negotiation of a new international legally binding instrument on marine biodiversity in areas beyond national jurisdiction (BBNJ) presents an opportunity for innovation in substantive law. This paper first illustrates how the BBNJ agreement can

1 UN Convention on the Law of the Sea (1982) 1833 UNTS 397 art. 86 (UNCLOS). <http://www .un.org/depts/los/convention_agreements/texts/unclos/unclos_e. pdf $>$; Agreement for the Implementation of the Provisions of the United Nations Convention on the Law of the Sea of 10 December 1982 relating to the Conservation and Management of Straddling Fish Stocks and Highly Migratory Fish Stocks (1995) 2167 UnTS 3 art. 5 (UNFSA); See Robin Allen, "International Management of Tuna Fisheries" (2010) 8-28 <http://www.fao.org/3/i1453e/ i1453eoo.pdf>. 
contribute to preventing disputes by explaining its basic four elements; next, it discusses apparent limitations in the scope of the agreement that could prevent it from performing that role; and finally, it turns to dispute settlement provisions to consider whether individual states have standing to represent community interests in a healthy ocean before ICTs, and whether non-state actors could be granted standing to represent the public interest (as they are in national courts). ${ }^{2}$

A New Opportunity: the B BNJ Negotiation

States embarked on this new treaty negotiation in 2018, under UN General Assembly resolution $72 / 249$. The agreement will add constructively to the regime for global cooperation in ABNJ by defining new roles and practices, and by expanding ocean governance from a narrow set of species - the fish which are the focus of numerous bi- and multilateral agreements - to all ocean biodiversity. The ввлј agreement's full name is explanatory: "an international legally binding instrument under the UN Convention on the Law of the Sea on the conservation and sustainable use of marine biological diversity of areas beyond national jurisdiction".

There are four elements to the negotiation. ${ }^{3}$ One, environmental impact assessment (EIA), will require notice and consultation on activities with significant impacts on the high seas environment, possibly when the effects take place in ABNJ. In addition to greater transparency, EIA in ABNJ should improve planning of activities and help address cumulative impacts on the ocean from all sources. Related to EIA, strategic environmental assessment may prove an even more effective tool to forestall conflicts and encourage sustainable use by providing a large-scale, long-term planning process. A second element, the use of area-based management tools (АВMT), including marine protected areas (MPAs), can clarify substantive rules. ABMT s can also enhance cooperation and coordination for protecting sensitive habitats and deconflicting human activities - for example, deep seabed mining, submarine cable laying, and trawling, which all take place on the seabed. The third element, capacity building and technology transfer, is intended to assist developing states to participate in the

2 Cour de cassation, criminelle, Chambre criminelle, 25 septembre 2012, 10-82.938, Publié au bulletin.

3 UNGA A/RES/72/249, "Internationally legally binding instrument under the United Nations Convention on the Law of the Sea on the conservation and sustainable use of marine biological diversity of areas beyond national jurisdiction", Seventy-second session, Agenda item 77, 24 December 2017, paras 1-2. 
treaty and in attaining its goals, especially by developing their marine scientific and technological capacity. Different in nature, the fourth topic addresses marine genetic resources especially of extremophiles and other life forms that inhabit environments of extreme cold, heat, or pressure and that are believed to have tremendous potential value for commercial products and other benefits to humans. The question of access to marine genetic resources and sharing monetary and non-monetary benefits of the products derived from them was included in the negotiation to promote fair and equitable use of marine genetic resources in $\mathrm{ABNJ}$.

\section{Institutional Cooperation Can Prevent Some Disputes}

Institutional cooperation structures and processes created by the BBNJ agreement could address sources of conflict. Three institutional structures are proposed that could prevent disputes arising from conflicts between ocean users: a Conference of the Parties (COP) as a high-level forum; a secretariat; and a scientific body that can function as a resource for evidence-based resource management and a medium for resolving scientific and technical disputes. ${ }^{4}$

The duty to cooperate is a substantive obligation central to the BBNJ agreement. It is already found in customary international law and Articles 63 and 116-118 of UNCLOS. Planning fostered through strategic environmental assessments that the ввN С СоР could authorize can identify long-term pathways for mutually productive stewardship and use of the ocean, using tools that include АВмТ s. This is the low-hanging fruit of conflict prevention.

However, the structure of the ввNJ negotiation mandate presents a challenge for de-conflicting sectoral activities in ABNJ. A phrase from the authorizing UNGA resolution is often quoted during meetings of the negotiating conference: "This Agreement shall be interpreted and applied in a manner that does not undermine relevant legal instruments and frameworks and relevant global, regional, subregional and sectoral bodies". It has been interpreted by some as excluding fishing from the agreement on the basis that fishing-related issues are already handled by RFMOs; similarly, that shipping is excluded by virtue of the International Maritime Organization regime and seabed mining by the 1994 Agreement implementing provisions of UNCLOS. If the agreement

4 Revised draft text of an agreement under the United Nations Convention on the Law of the Sea on the conservation and sustainable use of marine biological diversity of areas beyond national jurisdiction (2019), A/CONF.232/2020/3. 
concludes with this narrow approach, BBNJ will contribute little to the IUU fishing problem.

An alternative that would be better suited to the littered legal landscape and the interactions of human activities, including fisheries management, will provide opportunities for constructive inter-regime linkages. Proponents of this approach dispute that RFMOs are capably addressing marine conservation, including IUU fishing. The proponents of a stronger central role for BBNJ institutions point out that there are substantial gaps in the RFMO coverage of the world ocean. They argue that some RFMO s follow the advice of their consulting scientists only 17 to 39 per cent of the time. ${ }^{5}$ And RFMO s focus on target species but often overlook bycatch and non-fish species and habitats, in some cases because of a narrow legal mandate and in others because the primary purpose of the organization is fishery management.

Special Problems in the Nature of ABNJ Rights and Obligations

The advisory opinion on IUU fishing from ITLOs looks only at rights and obligations regarding IUU fishing and sustainable management within a coastal state's 200 nautical mile zone (EEZ), not the high seas. The special problems of applying the Tribunal's legal approach to the high seas are obvious. For instance, the coastal state's rights to manage the fishery within its EEZ apply against all other states, but no state has a territorial right to prescribe as against other states in ABNJ. While a coastal state has unique rights of possession and access within its EEZ, in ABNJ these apply equally to all states, as do the rights and obligations of conservation and marine environmental health. Yet there is an open question as to who can act as a rights holder where an obligation is owed to the international community. Two aspects to that question are: first, whether a state that does not have an individualized injury can enforce such rights; and second, whether a non-state entity such as an inter-or non-governmental organization should have a role in enforcing such rights. These questions can be considered in the context of formal dispute settlement, which as noted above, is both a tool of compliance and a normative influence.

Standing requirements, which might limit a complainant's access to a forum, are generally established by courts to ensure that the legal consequences of litigation are the result of a strenuously contested presentation of facts

5 Grantly R. Galland, Amanda E.M. Nickson, Rachel Hopkins, and Shana K. Miller, "On the importance of clarity in scientific advice for fisheries management", 87 Marine Policy (2018) pp. $250-254$. 
and law, to ensure that the parties affected control the conduct of the legal process, and sometimes to limit the number of cases that are allowed to draw on the costly resources of the ICT. ICT s do this by demanding that the claimant should have a strong interest at stake.

A traditional view has been that a state must have suffered special material or moral damage to trigger a legal claim; that the fact that a legal rule was violated is insufficient. ${ }^{6}$ According to the ILC Draft Articles on State Responsibility, a state that is an "injured state" can invoke the responsibility of another state if the obligation breached is owed to that state individually or "a group of States including that State". ${ }^{7}$ A state also can act if the obligation is owed to the international community as a whole and either the breach of the obligation specially affects that state or "is of such a character as radically to change the position of all other States to which the obligation is owed with respect to the further performance of the obligation". ${ }^{8}$ Thus a state may espouse the claims of the international community when it could have acted on its own behalf as well or in case of an (undefined) radical change in position of all other states.

ILC Special Rapporteur Crawford argued that "the principle that in certain cases any State had standing to protest against breaches of certain fundamental norms, and if necessary to institute proceedings to vindicate its interest as a member of the international community, has long been accepted". ${ }^{9}$ Judge Xue, in the ICJ Nuclear Negotiations case, recognized that the Marshall Islands "did not institute the proceedings merely for the protection of its own interest, albeit a victim of nuclear weapons. Rather the case serves more the interest of the international community".10 She continued, "[a]lthough the Court recognized obligations erga omnes in international law in the Barcelona Traction

6 For example, ILC, "Comments and observations received by Governments", A/CN 4/488 and Add.1-3 (1998), pp. 138-139 (comments by France on article 40).

7 "Draft Articles on Responsibility of States for Internationally Wrongful Acts", Yearbook of the International Law Commission (2001) Vol. II (Part Two) art. 42.

8 Ibid.

9 James Crawford, "Responsibility for Breaches of Communitarian Norms: An Appraisal of Article 48 of the ILC Articles on Responsibility of States for Internationally Wrongful Acts", in U. Fastenrath, R. Geiger, D. Khan, A. Paulus, S. von Schorlemer, and C. Vedder, (eds.), From Bilateralism to Community Interest: Essays in Honour of Bruno Simma (2011) p. 226.

10 Obligations concerning Negotiations relating to Cessation of the Nuclear Arms Race and to Nuclear Disarmament (Marshall Islands v. United Kingdom) Preliminary Objections, Judgement, I.C.J. Reports 2016, Declaration of Judge Xue, para 8; see also Dissenting Opinion of Judge Crawford, para 22. 
case $[. .$.$] it did not address the question of standing, locus standi, an issue that$ is yet to be developed in international law".11

BBNJ negotiating texts have provided for ITLOS contentious jurisdiction for states. ${ }^{12}$ A number of states, international organizations, and civil society organizations have also supported a provision that would confer advisory jurisdiction on ITLOS, consistent with the procedure affirmed in the IUU Fishing advisory opinion. ${ }^{13}$

\section{5}

\section{Non-state Actors}

Although some ICT s limit access to sovereign states, other dispute settlement fora are available to non-state actors. In the Responsibilities in the Area advisory opinion, the Seabed Disputes Chamber quotes approvingly the ILC's finding that a legal obligation can be "owed to the international community as a whole", ${ }^{14}$ and (as noted above) states that "entities engaged in seabed mining [and] other users of the sea" may be entitled to claim compensation for harm to the marine environment. ${ }^{15}$ This could be read to suggest that non-state entities could be subjects of international law entitled to litigate.

To seek reparations or other outcomes from an ICT, a claimant must either have standing before a court with jurisdiction, or it must have its claim espoused by a state. The ITLos Seabed Disputes Chamber appeared to lean toward an extension of the latter: it suggested that the International Seabed Authority might be able to act "on behalf' of [hu]mankind" or any state party might be able to bring a claim "in light of the erga omnes character of the obligations relating to preservation of the environment of the high seas and in the Area". 16

To see whether ITLOS could be a forum for non-state actors, one must look at UNCLOS, which created the tribunal, and its Statute. Part XI of UNCLOs, Article 187 provides jurisdiction for non-state actors: that is, the International

\footnotetext{
11 Ibid. (citations omitted).

12 For example, Draft text of an agreement under the United Nations Convention on the Law of the Sea on the conservation and sustainable use of marine biological diversity of areas beyond national jurisdiction (2019), A/CONF.232/2020/6.

13 Request for an advisory opinion submitted by the Sub-Regional Fisheries Commission, Advisory opinion, 2 April 2015, ITLOS Reports 2015, p. 4 (SRFC), paras 52-6o.

14 Responsibilities and obligations of with respect to activities in the Area, Advisory Opinion, 1 February 2011, ITLOS Reports 2011, p. 10, para 180.

15 Ibid., para 179.

16 Ibid., para 18o.
} 
Seabed Authority, state enterprises and certain natural or juridical persons, but for limited purposes. More broadly, the IT Los Statute, Article 20, provides for access to states parties and "entities other than States Parties [...] in any case submitted pursuant to any other agreement conferring jurisdiction on the Tribunal which is accepted by all the parties to that case". The first application of Article 20 was Case No. 21, the advisory opinion sought by the Sub-Regional Fisheries Commission (SRFC). In that case, the Tribunal analysed whether its requirements for jurisdiction, stated in Article 138 of its Rules, had been satisfied:

an international agreement related to the purposes of the Convention specifically provides for the submission to the Tribunal of a request for an advisory opinion; the request must be transmitted to the Tribunal by a body authorized by or in accordance with the agreement mentioned above; and such an opinion may be given on "a legal question".

The Tribunal determined that the SRFC had satisfied the conditions for advisory opinion jurisdiction. ${ }^{17}$ The SRFC is not a "state party" to UNCLOS, so Case No. 21 is an example of ITLOS standing by an entity other than a state party. However, the SRFC is a treaty-based body comprising UNCLOS parties. Similarly, a future BBNJ agreement could provide for ITLOS advisory jurisdiction; the obvious body to exercise the authority would be its own conference of the parties, but it is theoretically possible that other bodies might be so authorized.

Traditional rules of public international law, under which non-state actors are not international legal persons, are being stretched in new claims. The Gambia's successful espousal of the interests of the Rohingya against Myanmar before the ICJ is an example. ${ }^{18}$ The experiment has not been tried, whether a state-sponsored claim on behalf of a non-governmental organization representing the international community's interests (for example, in marine biodiversity conservation) would be accepted by the ICJ, though Bothe explains that this effectively occurred in the Nuclear Tests case without the NGO (Greenpeace) being named in the case. ${ }^{19}$ Previous cases suggest that it

17 SRFC (supra note 13), paras 6o-66.

18 Application of the Convention on the Prevention and Punishment of the Crime of Genocide (The Gambia v. Myanmar), Order for Provisional Measures, 23 January 2020.

19 Michael Bothe, "Compliance Control beyond Diplomacy - the Role of Non-Governmental Actors”, 27(4) Environmental Policy and Law (1997) pp. 293, 294. 
might; for example, in Elettronica Sicula S.p.A. (ELSI) ${ }^{20}$ and the Arctic Sunrise Case $^{21}$ the United States and the Netherlands, respectively, espoused the rights of a company and a public interest organization that were their nationals. It has been suggested that there may be a distinction between these diplomatic protection cases, where the losses were individualized with respect to the organizations concerned, and state espousal of the community losses that are proposed here. However, where a state is the claimant, the question of individualized interests does not arise. The Nuclear Tests case is not the only example where a state espoused community interests: the World Trade Organization Dispute Settlement Body, for example, considered 'contemporary concerns of the community of nations about the protection and conservation of the environment', as highly relevant in its decision regarding migratory sea turtles that transit national waters and the high seas. ${ }^{22}$

While states are traditionally the only subjects of international law, the question of legal personality has already been resolved in favour of non-state actors in many contexts. They function as amici in interstate disputes; they are observers in treaty negotiations where they observe, propose text, provide expertise, bear witness, and lobby. Non-state actors represent environmental interests, business, youth and the "Major Groups" that were recognized in Agenda 21 as having a role to play in international society. ${ }^{23}$ The UNFCCC regularly engages with non-state actors as environmental non-governmental organizations (ENGOS), research and independent NGOS (RINGOS), business and industry NGOS (BINGOS), and trade union NGOS (TUNGO S). Human rights courts allow individuals, communities, and indigenous groups to bring claims against states. UNCLOS itself provides for special standing before the Seabed Disputes Chamber for mining contractors and the International Seabed Authority, as discussed above.

In particular, through investment treaties, states bargained to grant special access rights to international arbitration to foreign investors in projects within their territory. Obviously, there is no inherent bar to treaty-based standing for

20 Elettronica Sicula S.p.A.(ELSI) (United States of America v. Italy), Judgment, I.C.J. Reports 1989, p. 15 .

21 The Arctic Sunrise Arbitration (Netherlands v. Russia), Provisional Measures, ITlos Case No 22 (2013).

22 US - Import Prohibition of Certain Shrimp and Shrimp Products, WT/DS58/AB/R, 12 October 1998, para 129.

23 Agenda 21 (1992), A/CONF.151/26 (vol. III), sec. III: Major groups (women, children and youth, indigenous people, NGOs, local authorities, workers and trade unions, business and industry, the scientific and technological community, and farmers) should be supported financially and administratively. 
non-state actors. It is submitted that there is no principled or legal reason that special international standing should be granted to economic entities but not to other civil society entities - including the indigenous communities that have an important role in the Arctic. The only apparent reason for the current special access by economic entities to the international judiciary is that the nations that negotiated the treaties granting them standing believed it to be in their national interest.

If this is correct, then the question is whether it is in the interest of sovereign states to agree that representatives of the international community can use international courts. The answer, briefly stated, is that it would serve the same sovereign interests that are served by having civil society participation in international institutions, and civil society litigants in national courts. That is, it can serve to overcome the problem that although humanity may need the oceans to be protected, individual states may be constrained or merely uninterested in taking legal action. ${ }^{24}$ Further, it increases democratic legitimacy.

вBNJ institutions designed to lead effective cooperation with other regimes should be considered strengthening, not undermining, to the legal order of the ocean. IUU fishing is, in some respects, a consequence of a weak legal regime. International community interests in the ocean beyond national jurisdiction include conservation and use that is sustainable; the economic interests emphasized in other instruments may be enhanced and strengthened in the long-term by the вв strategic environmental assessments (SEAs), and Area-Based Management Tools - and its capacity building and technology transfer provisions.

It is recognized that it is desirable to engage the international community through both states and non-state actors where important rights and obligations are at issue. The BBNJ agreement can do this by granting observer status to civil society organizations, accompanied by strong support for their participation. Such measures to protect the public interest would be analogous to the provisions that carefully protect the commercial interests of seabed miners and fishers in international agreements.

24 Crawford 2011 (supra note 9) p. 225: "Better to give States standing in Court to protect what they perceive as global values than to leave them only with non-judicial means of dispute settlement, whether in the guise of countermeasures or under the rubric of 'responsibility to protect"'. 
Finally, restrictions on access to ICT s is a legacy of a past era, where states engaged with each other in limited ways, and rarely in areas outside state territorial jurisdiction. In today's crowded world, where existential interests of humanity are at stake, states and non-state actors with the capability of representation can and should also be recognized to have the competence to access judicial fora. 